\title{
PREFIGURING HOUSES IN A TRADITIONAL CITY: A CASE FOR BENIN HOUSE TYPES AND CHARACTERISTICS
}

\author{
Eghosa Noel EKHAESE ${ }^{\mathrm{a}}$, Bayo AMOLE ${ }^{\mathrm{b}}$, Oladunni IZOBO-MARTINS ${ }^{\mathrm{c}}$ \\ ${ }^{a, c}$ Department of Architecture, School of Environmental Studies, Covenant University, Ota, Ogun, Nigeria \\ ${ }^{b}$ Department of Architecture, Faculty of Environmental Studies, Obafemi Awolowo University, Ile-Ife, Osun, Nigeria
}

Received 01 September 2014; accepted 01 December 2014

\begin{abstract}
House mean different things to different people. House could be a dwelling, home, hut, place for; entertainment, rest, sleeping, receiving guest, and a palace. The interpretation of house as shelter makes it a basic necessities of life. Thus the focus of the paper is to identify and document house types in Benin by observing the physical characteristics and type's classification from the organization and pattern of architectural plan documented. The study explored qualitative and quantitative approach using observations, descriptive frequency, architectural sketches, photographs and interview guide. The findings revealed a cross sectional characterising and classifying houses in Benin City, Nigeria which reflect the typical cross section structure of a traditional city. The result of study would however, influence professional in built environment and policy maker decision positively.
\end{abstract}

Keywords: prefiguring, traditional Nigerian city, house, types and characteristics.

\section{Introduction}

The paper presents the data collected in Benin City, which includes: architectural floor plans of houses in Benin and socio-physical characteristics of each house-type. To collect the data, measured drawings, photography and systematic observations was used to record physical characteristics of house-types and domestic space use. Several house-types were identified in Benin and grouped under four residential zones across the City (core, intermediate, suburban and planned estates) (Ogu 1995). The selections, analysis and documentation of house-types were carefully done, based on series of observations and examination. In the end, certain characteristics were adopted for classification of identified house-types. Table 1 shows the number of selected residential houses in the sample collected across the four residential zones in Benin City.

\section{Study area}

Benin City is located at latitude $06^{\circ} 19 \mathrm{IE}$ to $6^{\circ} 21 \mathrm{IE}$ and longitude $5^{\circ} 34 \mathrm{IE}$ to $5^{\circ} 44 \mathrm{IE}$ with an average elevation of $77.8 \mathrm{~m}$ above sea-level. Benin City is a pre-colonial city and is underlain by sedimentary formation of MiocenePleistocene-age often referred to as Benin formation. The city is located in humid tropical rainforest belt of Nigeria with a population of 762,717 from 1991 national population census, but with a projected population of 1.3 million by 2010 at $2.9 \%$ growth rate. Benin City belongs to AF category of Koppen's climatic classification and has witnessed rapid territorial expansion mainly due to rapid rural-urban migration and it is the capital of Edo State, Nigeria (Omoigui 2005). According to USAID reports in 2002, Edo State was estimated to have a population of 2.86 million; 64.47\% live in Benin City (i.e. about 1,035,995

Table 1. Numbers of selected residential houses in the four zone of Benin

\begin{tabular}{|l|c|c|c|c|}
\hline \multicolumn{1}{|c|}{ CITY/TOWN } & \multicolumn{4}{|c|}{ Four Residential Zones (Location Of Houses) } \\
\hline $\begin{array}{l}\text { Benin City (Total No. Of } \\
\text { Residential Houses) }\end{array}$ & Core Zone & Intermediate Zone & Sub-Urban Zone & Planned Estate Zone \\
\cline { 2 - 5 } & $104(100 \%)$ & $353(100 \%)$ & $459(100 \%)$ & $136(100 \%)$ \\
\hline
\end{tabular}

Source: Ekhaese (2011).

*Corresponding author. E-mail: noel.ekhaese@covenantuniversity.edu.ng 
inhabitants), making it similar in size to Jamaica with a population of ( 2.74 million) and bigger than Botswana (1.6 million) and Trinidad and Tobago (1.1 million). Edo State has eighteen (18) Local Government Areas. The Edos as people are known, have cultural perspective and approach to life, with strong belief in religion and traditions which has set a spiritual and temporal authority for royal leadership in the State. The traditional forms of worship are being diluted by modern religious faiths. This has influenced the domestic architecture, so that contemporary architectural style is emerging along City peripheries and new expansions.

\section{Literature review}

\section{The concept of a city}

Like most concepts in research, city concepts exist across the literature. Bertaud (2004) describe a city as an inhabited central place differentiated from a town/village by its size and range of activities like religious, military, political, economic, educational and cultural within its boundaries that involve exercise of power over surrounding villages. Until very recently, people lived on farms in minuscule rural villages. The world's first cities, Tigris and Euphrates now Iraq and Pakistan, emerged around 3,500 BC (5,500 years ago) in the Nile valley, Egypt from ethnographic evidence (Stark, Simon Fan 2007). In traditional societies, cities were very small. Babylon (i.e. largest cities) covered 3.2 square miles with about 20,000 people. Today, cities are acknowledged as major centres of economic opportunity, education and cultural life. As engines of cultural life and home to cultural heritage and events, cities serve as a source of cultural identity and societal transformation and man as a social being has always lived in groups. This perhaps is man is in constant interactions and social relationship with other members of society for continued relevance and existence (Mills, Byong-Nak 1979). Therefore the dominant characteristics of a city includes: relatively dense and heterogeneous human population, Social Distance, regular Lifestyle/Living Conditions and Overcrowding. Most traditional cities shared certain common features especially high walls and the central area was usually occupied by place of worship, royal palace, government/ commercial buildings and a public square. The ruling class tends to be concentrated near the Centre areas unlike the other groups found around the city perimeter/outside the city (Ekhaese, Adeboye 2014b).

\section{The idea of a traditional city}

In traditional cities, the outward pattern connecting houses to street reflected the need to maintain sense of belonging, neighbourhood and interest in community activities involving the urban environment. In traditional cities core, houses are more open to outside (Assari et al. 2012). The attitudes might have resulted from the self-sufficient agricultural economy of traditional cities. The pressure for exchange of goods and technological innovations were limited. Productions were organized on a family scale. Land, agricultural technology, and other assets were passed from generation to generation within the family (Li 1985). Naturally, the family became the basic unit of society and urban residents kept the same behaviour, since Traditional Nigerian Cities were closely tied to the rural area. Respect for family encouraged the worship of others (Saga 2012). However, Benin City like European medieval towns had two major public open spaces, the market/city-hall square and the palace with different functions, but used together daily by all city residents. The relationship was often revealed by a physical connection between the two spaces (UNESCO 2010). Benin Traditional city has a centre that was spatially separate and functionally distinct in usage, as shown in Figure 1. The core included the palaces government house, offices, legislative house, market and open spaces (Ekhaese 2011). In traditional orthodox belief, the palaces at city core are the most conspicuous places on city maps. The physical settlement forms in Nigerian traditional cities revealed the social and cultural intentions of the society as a whole. The study however, identified five key values/beliefs that shapes settlements, this include: maintaining social hierarchy, honouring centralised monarchy, strengthening family and kinship importance, creating a holistic environment and making full use of natural opportunities (Ramezan, Hamidi 2010). More formal characteristics of traditional

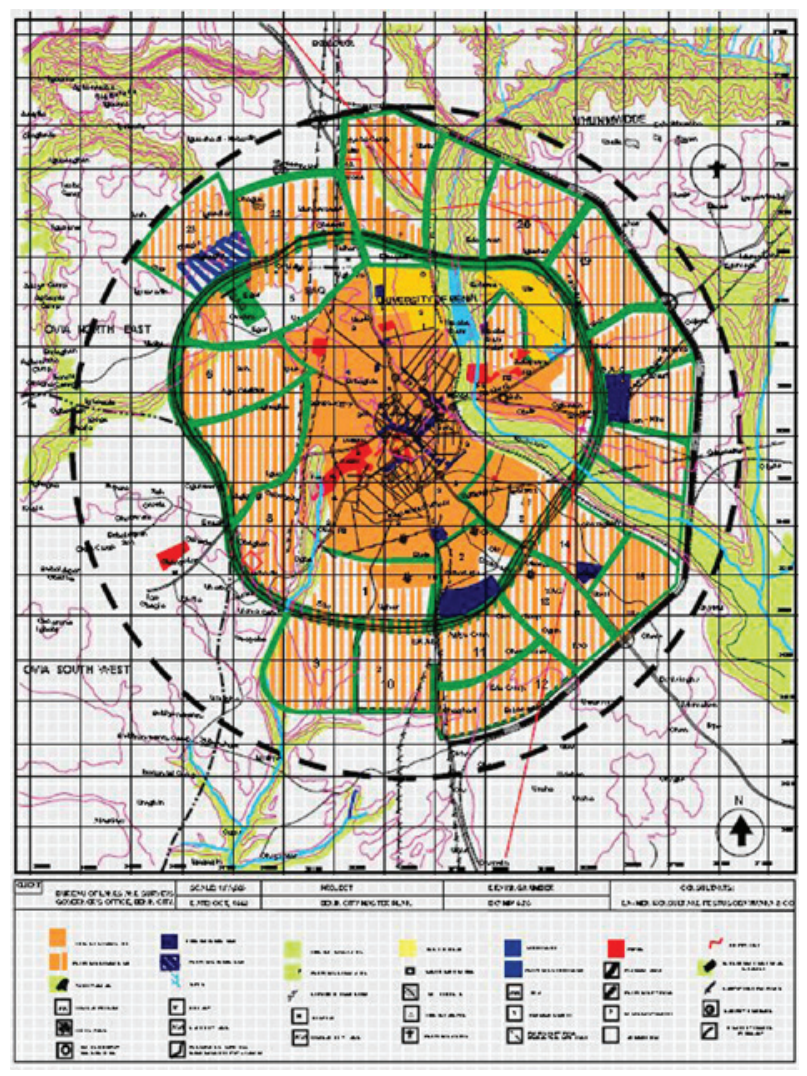

Fig. 1. Plan of Benin-city showing the existing form Source: Abakare (2013). 
Nigerian cities may have similar significance for the definition of the settlement type. It is difficult to describe a traditional Nigerian city through plans alone. So, the total cultural background of traditional Nigerian people should be examined to fully understand the most fundamental issues

In order to attain the new state, traditional cities had traversed an extremely difficult and enduring idea, that cities were first a, mechanic effigies to the modern order (Li 1985). Built against nature and designed to contain and control humanity, traditional cities were places where humanity lost its organization and became separated and withdrawn from nature. Beyond work and residence, it was difficult to see what other purposes cities were to serve (Miao 1990). As always, change was controlled by those whose interests had become alienated and who practiced different values. Interestingly, the tightly controlled planned city did not sit well with growing demands for freedom and variability and the new creative cities manifested a freer, more tolerant, consumerist and entertaining ethos. The study appreciates the efflorescence of city life and recognises how Nigerian traditional city was transformed by modernity. This is largely a story of building of new cities and the various makeovers of older cities after their image (Ju et al. 2015).

\section{Pattern of a traditional city}

Traditional city, are usually first mono-centric, the monocentric pattern has been the model most widely used to analyze spatial organization of cities. Alonso (1964), Muth (1969), and Mills (1972) believe that density gradients in metropolitan areas are based on hypothesis of a monocentric city.

It has become clear over the years that the structure of many cities proceeded from the mono-centric model and that many trip-generating activities were spread in clusters over a wide area outside the traditional CBD as shown in Figure 2. As city grow in size, the original mono-centric structure of large metropolises tends with time to thaw progressively into a polycentric structure. The CBD loose its dominance, and clusters of activities generating trips spread within the built-up area (Bruekner 2001). A monocentric city can maintain a unified labor market by providing the possibility of moving easily along radial roads from the periphery to the core. This typifies the structure of most Nigerian traditional cities, especially Benin City. A metropolis constituted by self-sufficient "municipal villages" would contradict the only valid explanation for the existence and ideally. The municipal village concept is the ultimate labour market fragmentation. Although there are many polycentric cities in the world, there is no known example of an aggregation of small self-sufficient communities. However, the ideal concept of a polycentric city as a cluster of municipal villages persists in the mind of many planners (Bertaud 2004).

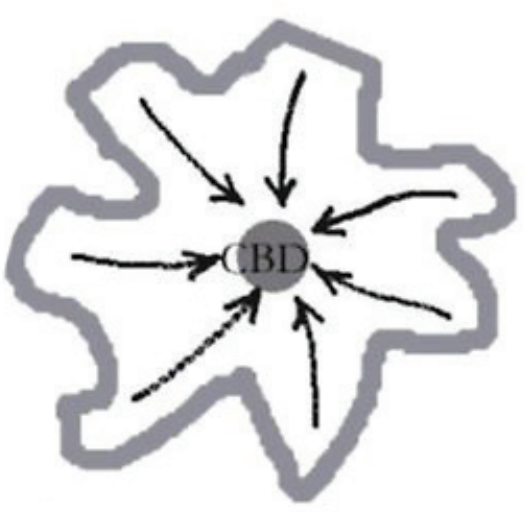

Fig. 2. Mono-centric model of a traditional city Source: Bertaud (2004).

\section{Study methodology}

In the study, a total of one thousand and fifty-four (1054) houses were selected across the cross section of residential zones in Benin-City. Houses were identified, characterised and classified into types based on physical organization and space morphology. The classification showed that eleven (11) house-types were identified across four residential zones in Benin. In the core residential zone, a total of 104 houses were documented and grouped under three (3) house-types. And in intermediate residential zone 353 houses were sampled and grouped under seven (7) house-types, In sub-urban residential zone, 459 houses were documented and clustered into five (5) house-types. And in planned estate residential zone, 136 houses were selected and categorised under four house-types as shown in Table 2.

\section{Results, Findings and Discussion}

A study of the City, from observations, and deductions from interview of key informants (i.e. custodians and practitioners of architecture and culture) conducted revealed that, transformation has been gradual across the entire city. Identifying house-types resulting from changes in culture, lifestyle, believes, economy and development, it was clear that house-types varied across four residential zones i.e. core, intermediate, sub-urban and planned estate. However, classifying the houses into types was based on spaces organization and use (Ekhaese, Amole 2014a). The houses in each zones represented houses built at different periods in the City development. The core zone houses are oldest while planned estates are the newest. Other characteristics examined included age of construction, number of households, house owner and construction materials. The variables across four residential zones were used to describe each house after preliminary classi- 
Table 2. The house-types as identified during the field survey

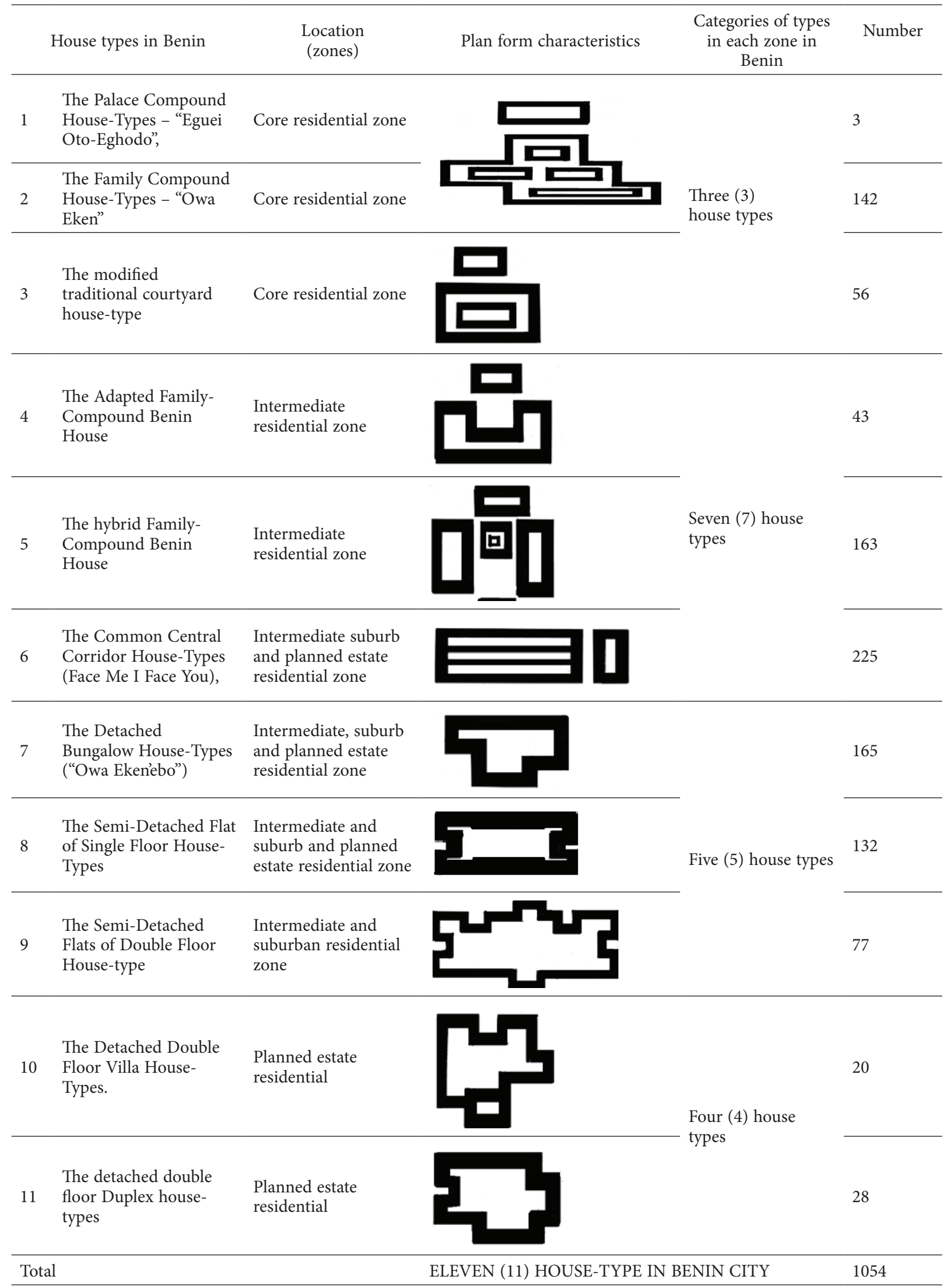

Source: Ekhaese (2011). 
fication into types based on floor plan. The sketched houses plans documented in the paper were as obtain from the author's field work.

\section{Traditional courtyard house-type (Impluvium Design)}

There are two types of Edo traditional courtyard houses according to Dr. Aisien "palace and family compound house-types". The traditional courtyard houses may be different in quality and complexity, but there are usually considerations for public and private areas (Aisien 2001).

\section{The palace compound house-types}

The palace compound houses are planned such that rooms are arranged around a series of internal courtyards (Fig. 3), leading one into the other, like Classical Roman house with its sequence of atria (Agbontaen 1997). Chief Isekhure- the Isekhure of Benin in describing Benin traditional compound house said "The courtyard is an opening which admit light and air, below the floor is a sunken impluvium with an outlet to carve away storm water". The internal courtyard has typical Mediterranean feature and may be with/without a peristyle of columns, depending on the size. A common feature is couches and shrines constructed of mud, with high-glaze-polished-surface of an enduring quality, like it was recently built (Ekhaese 2011). The sequence of courtyards flows from household head apartments to wives' and boys apartments each side. Externally the mud walls are finished in a pattern of horizon- tal ribs, a fashion which has practically continued, (Fig. $3)$. The original thatched roofs have been replaced with corrugated iron, although the old method of providing a thatched coping on a light-wooden-framework to the tops of courtyard walls still persists. The roof construction is done with heavy timbers carefully framed together around the roof opening. The doors are carved-ornamented-doors with ornamented jambs and wooden posts supporting the peristyle around larger courtyards in a rather unimpressive exterior.

\section{The family compound house-types}

According to chief Edebiri- the Eson Madagua of Benin "An outer corridor usually about $12-16 \mathrm{ft}$ long has servant's rooms on both sides. The corridor leads to the worship and celebration courtyard (7-9 rooms). From the main courtyard a narrow lobby leads to Ikun n'derie wives' Harem and children's harem on the right connecting backdoor leading to kitchen and convenient". Figure 4 is rectangular-shaped-hollow large structure with seven levels high and four courtyards. It is divided into public area includes sitting room, store and courtyard and private area includes back lobbies, kitchen and bedrooms. Front section (servants and visitors spaces), side section (household head "Egun") and back sections (wives and children). It has main parlour in front with a door leading to the fore-courtyard, where the shrine is. From the entrance, there is a space connecting the exterior veranda and internal corridors accessing the courtyards. The rooms are usually around courtyards and harems
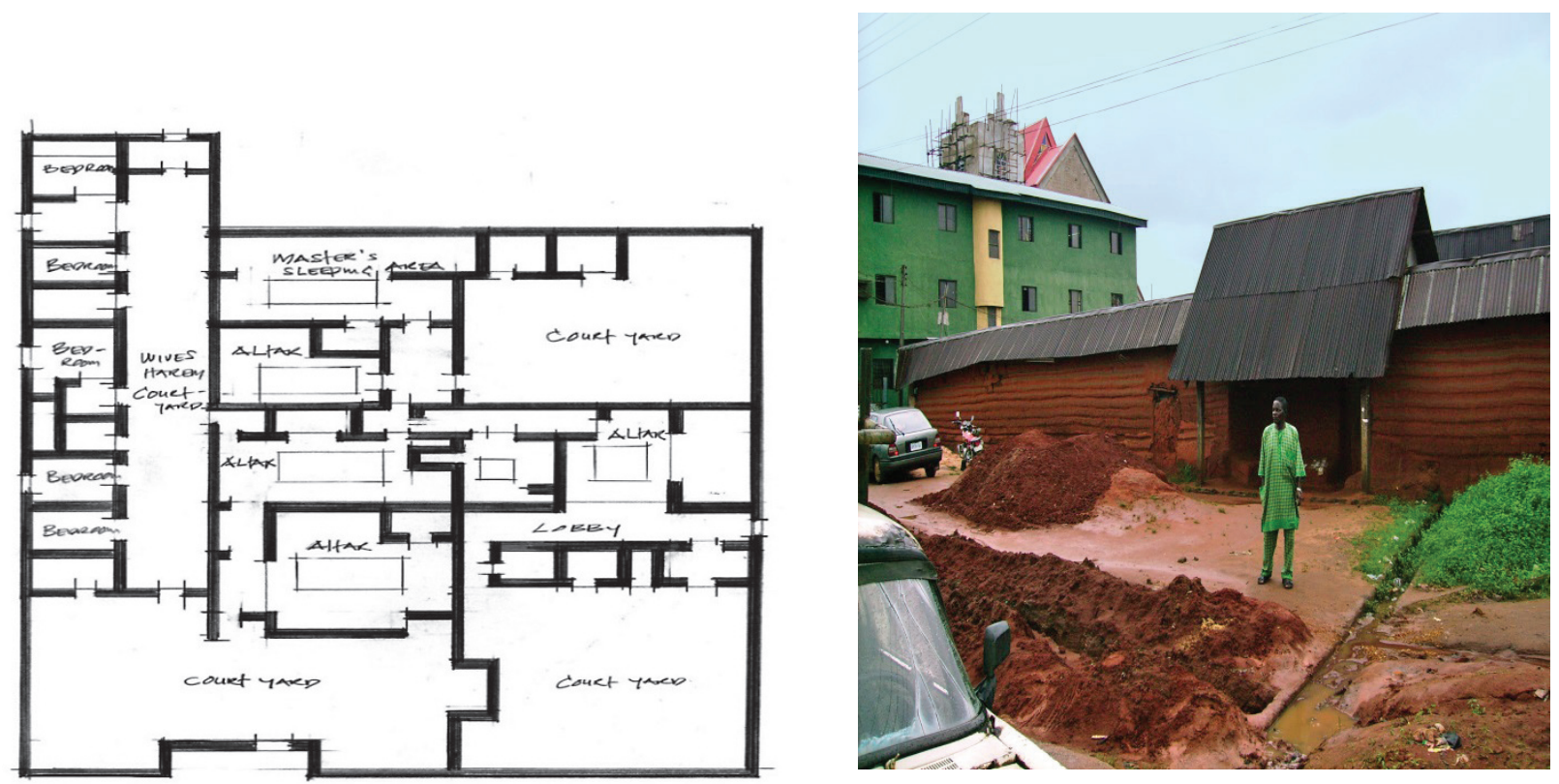

Fig. 3. Floor plan and picture of a typical palace-compound Benin house Source: Ekhaese (2011). 

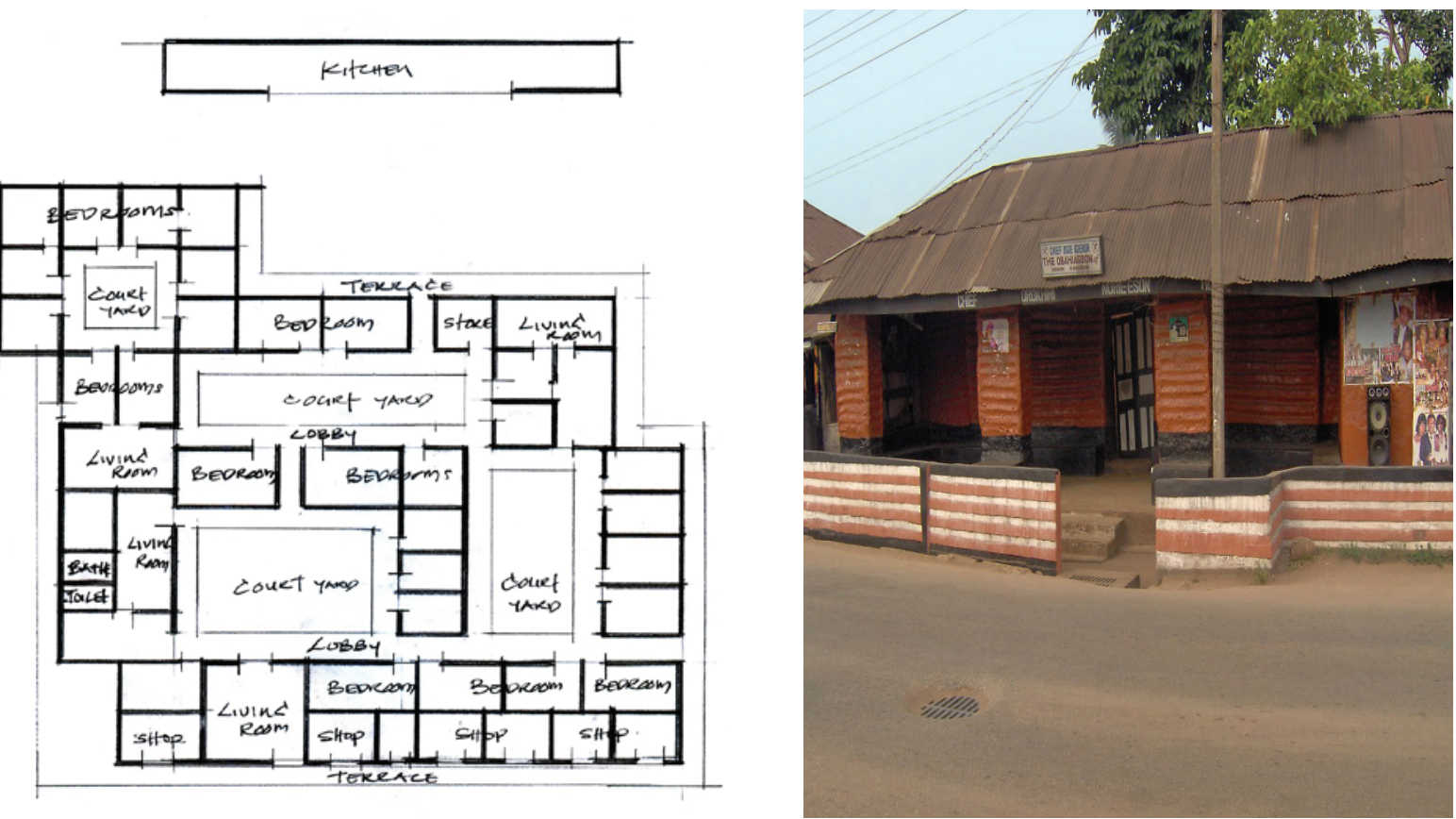

Fig. 4. Floor plan and picture of a typical family-compound Benin house Source: Ekhaese (2011).

always at the back. The house is properly ventilations, lighted and environmentally friendly. The Benin family compound house-type was started in $5^{\text {th }}$ century. The courtyard is used for receiving guests, performs rituals, judges and settles misunderstandings etc. (Agbontaen et al. 1996).

\section{The modified traditional courtyard house-types}

This house-type is an improvement on the Family Compound House. They are found mostly in intermediate zone and sub-urban zone. The study characterized it as modified courtyard house because it is an upgrade of the traditional courtyard house. The house-type was started around $19^{\text {th }}$ century, using Edo traditional courtyard concept with some alterations. The floor plan has only one courtyard which can be either closed-end/open-ended. These two classes of courtyards divide this category into three house-types. This includes; family compound, adapted family compound and hybrid family compound courtyard house-type. Modern building materials are used for construct. In an interview with Chief Sam Egbe - The Iyasere of Benin, he stated that "the numbers of courtyards were reduced from between 5-201 to 1 due to reduced family size and modified to accommodate tenants". The courtyard is usually surrounded by paved walkways with sitting room and bedrooms of different sizes. Around the compound are long verandas from front to back sections. This is typical of the traditional courtyard house in Benin (Fig. 5).

\section{The adapted family-compound house-type}

The adapted family compound house is a category in modified traditional courtyard house. It is called adapted because it has an open-ended courtyard that is almost enclosed at the back with shrine, kitchen, convenience and storage. The compound usually has two/more buildings with an open-ended-outward-looking courtyard, unlike other house-types, where all rooms around the courtyard face it. The courtyard of the adapted family compound is towards the back. This particular plan (Fig. 6) has a garage, living rooms, and open-ended courtyard. Towards the back is the worship building and attached to it are spaces for kitchen, stores and utilities.

\section{The hybrid family-compound house-type}

The hybrid family compound house is a modified traditional courtyard house-types. It has an outwardlooking-open-ended courtyard like adapted family compound house-type, but the difference is that the open-ended courtyard is either open to the back/front without any smaller building enclosing it. The housetype is known as hybrid because it combines more than one category of house-type together to form a compound. Figure 7 below combines both corridor house and detached bungalow house to form the "hybrid family compound" house. 

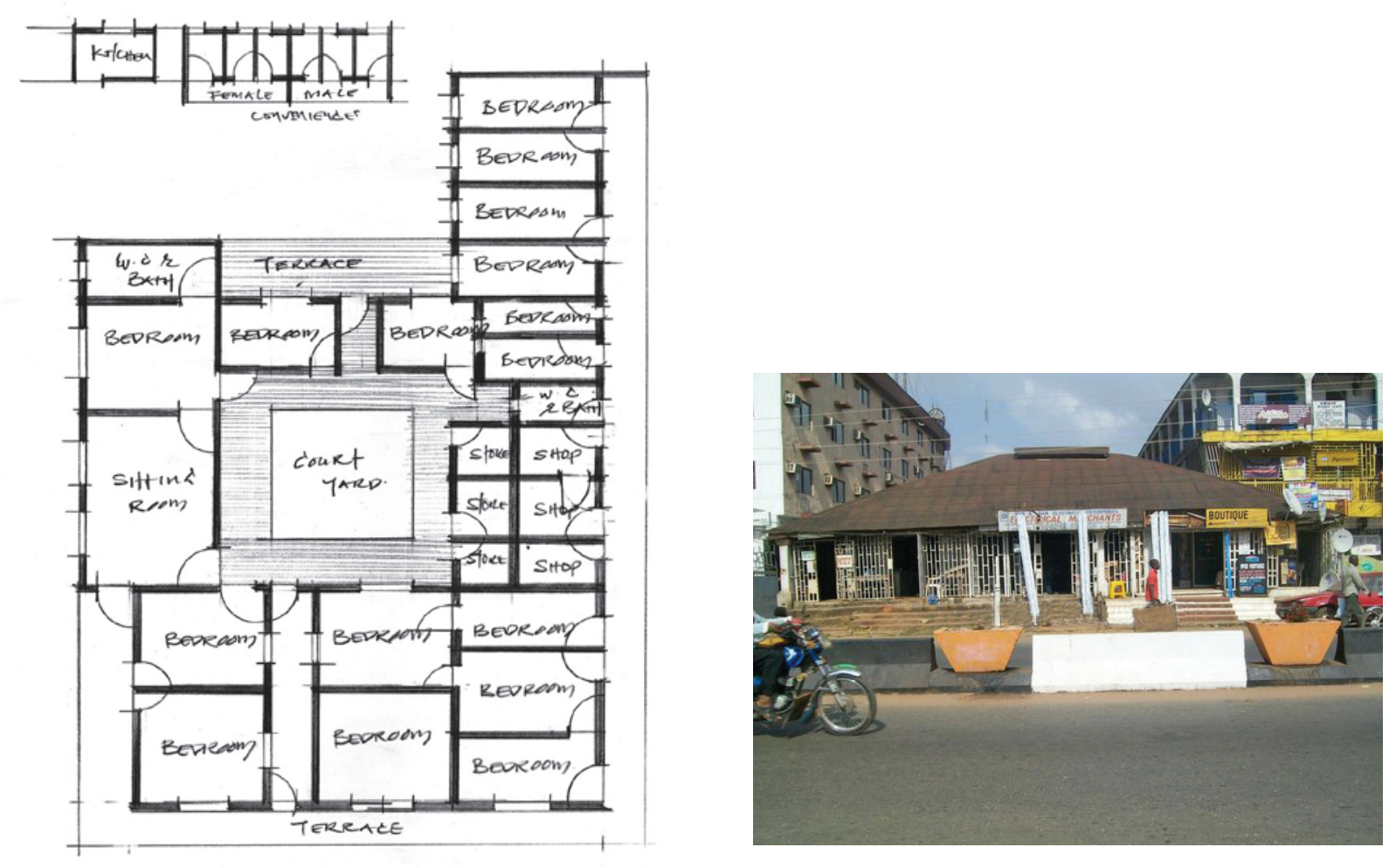

Fig. 5. a Typical modified family-compound Benin house

Source: Ekhaese (2011).
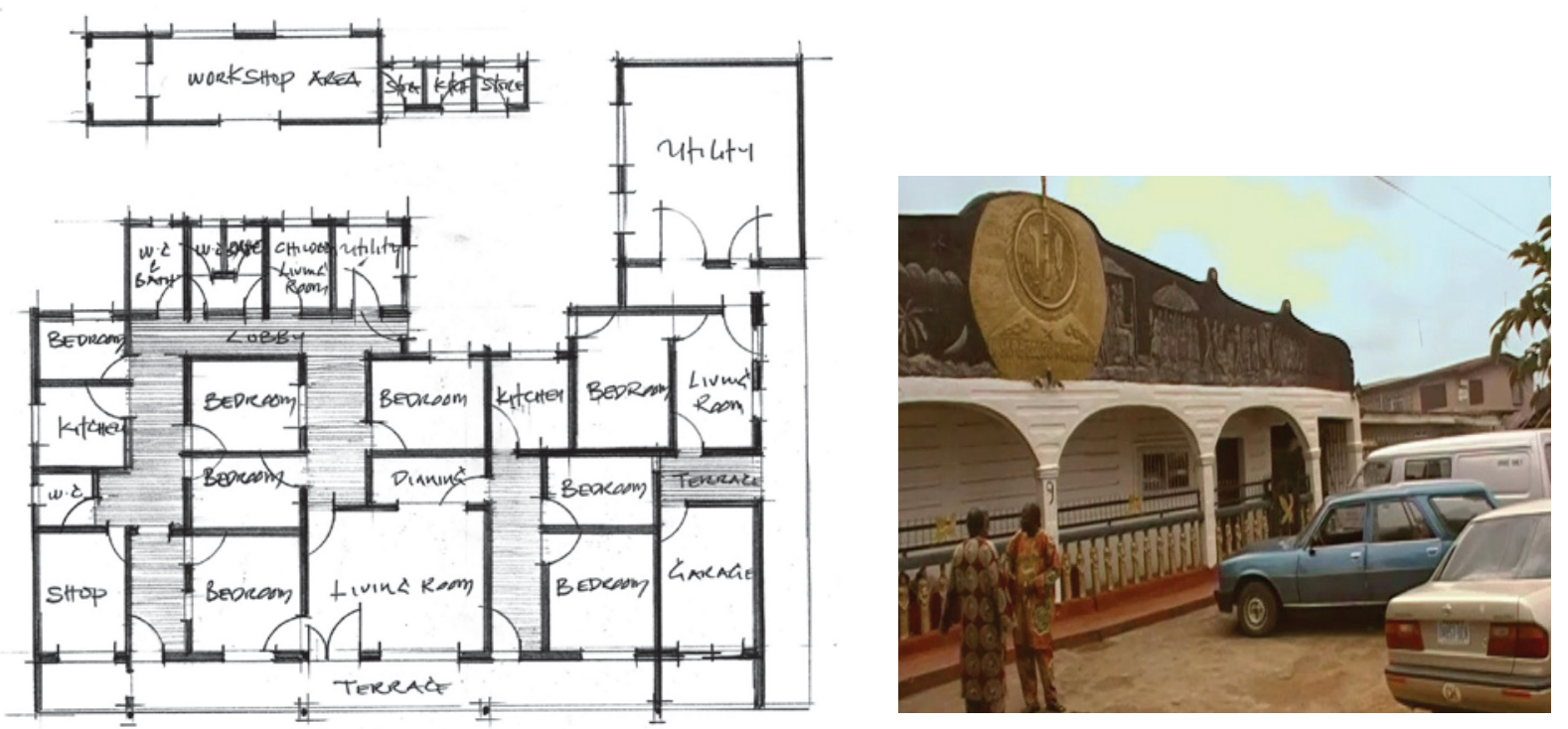

Fig. 6. Floor plan and picture of a typical adapted family-compound Benin house Source: Ekhaese (2011).

The corridor house-types (face me i face you)

This house-type is a corridor house (otherwise known as "face me I face you"). The courtyard in traditional courtyard house has been reduced into a long internal corridor with rooms on either side and it is terminated at the back by kitchens, stores, toilets and bathrooms. Figure 8 has an internal corridor with rooms on either side. The corridor house plan is accessed from a small terrace at the entrance. All rooms in the house are accessed from the corridor and it is called "face me I face you" because all rooms doors on one side of the corridor faces all room doors on the other side. 

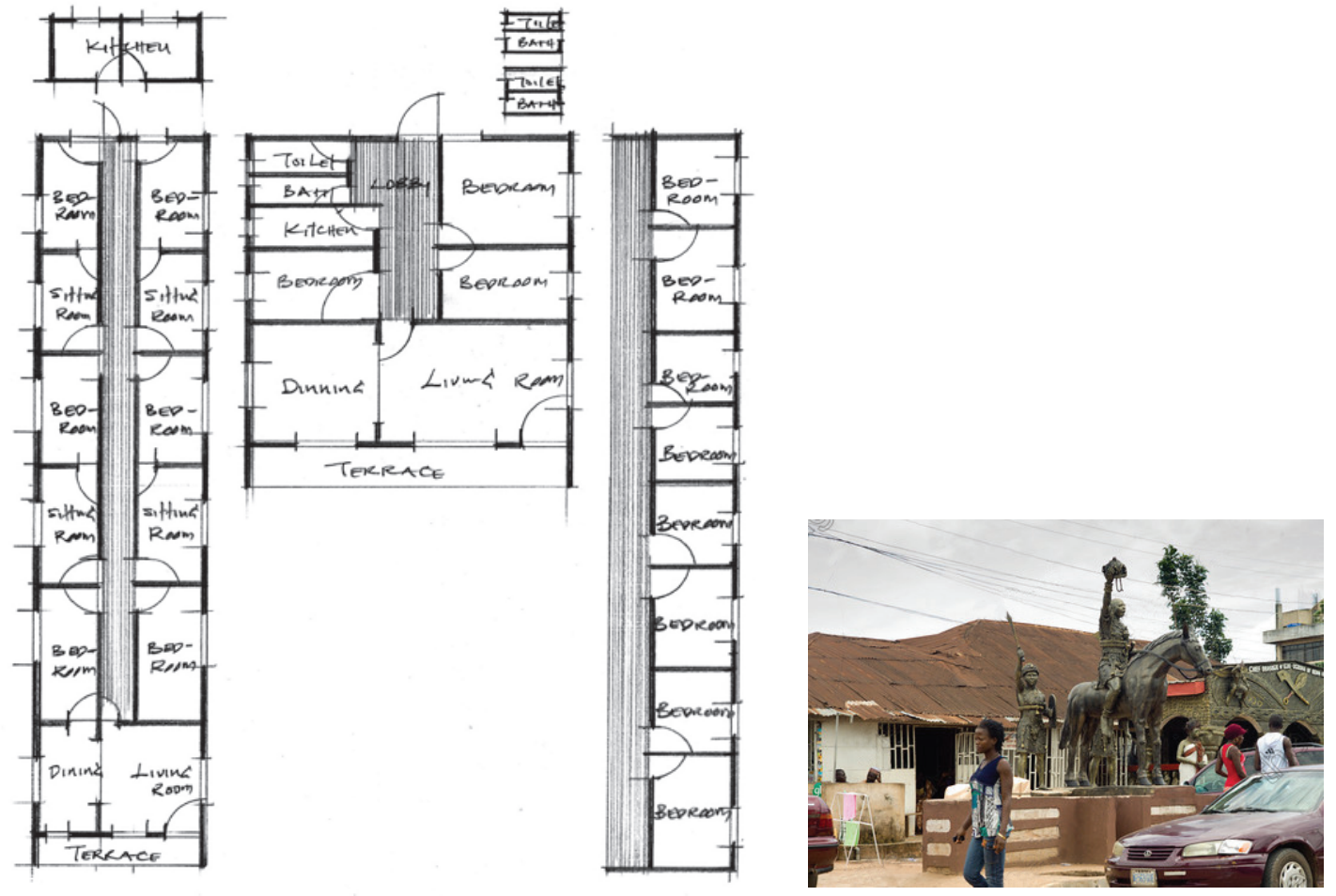

Fig. 7. Floor plan and picture of a typical hybrid family-compound Benin house

Source: Ekhaese (2011).
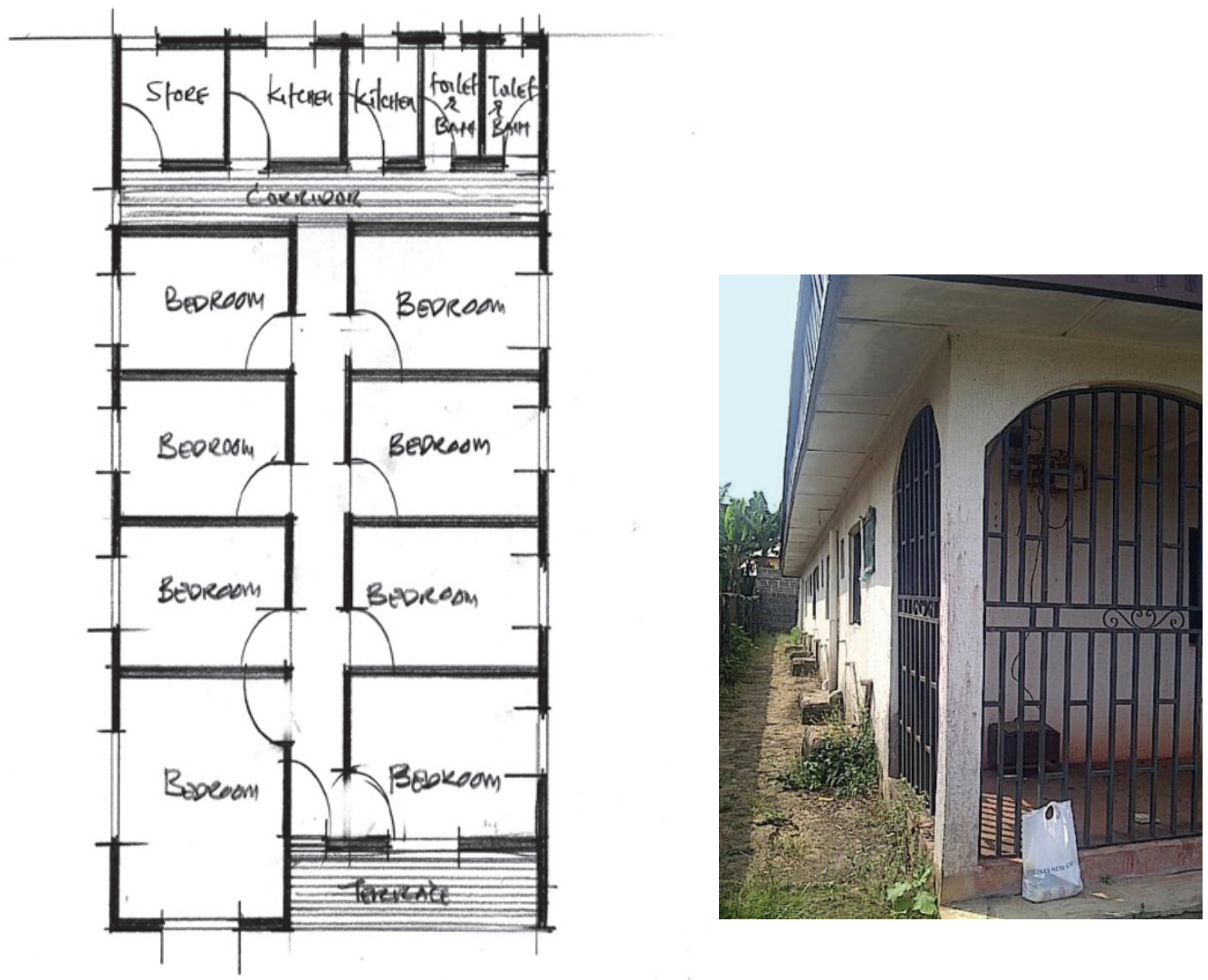

Fig. 8. Floor plan and picture of a typical face me i face you" corridor house-type

Source: Ekhaese (2011). 

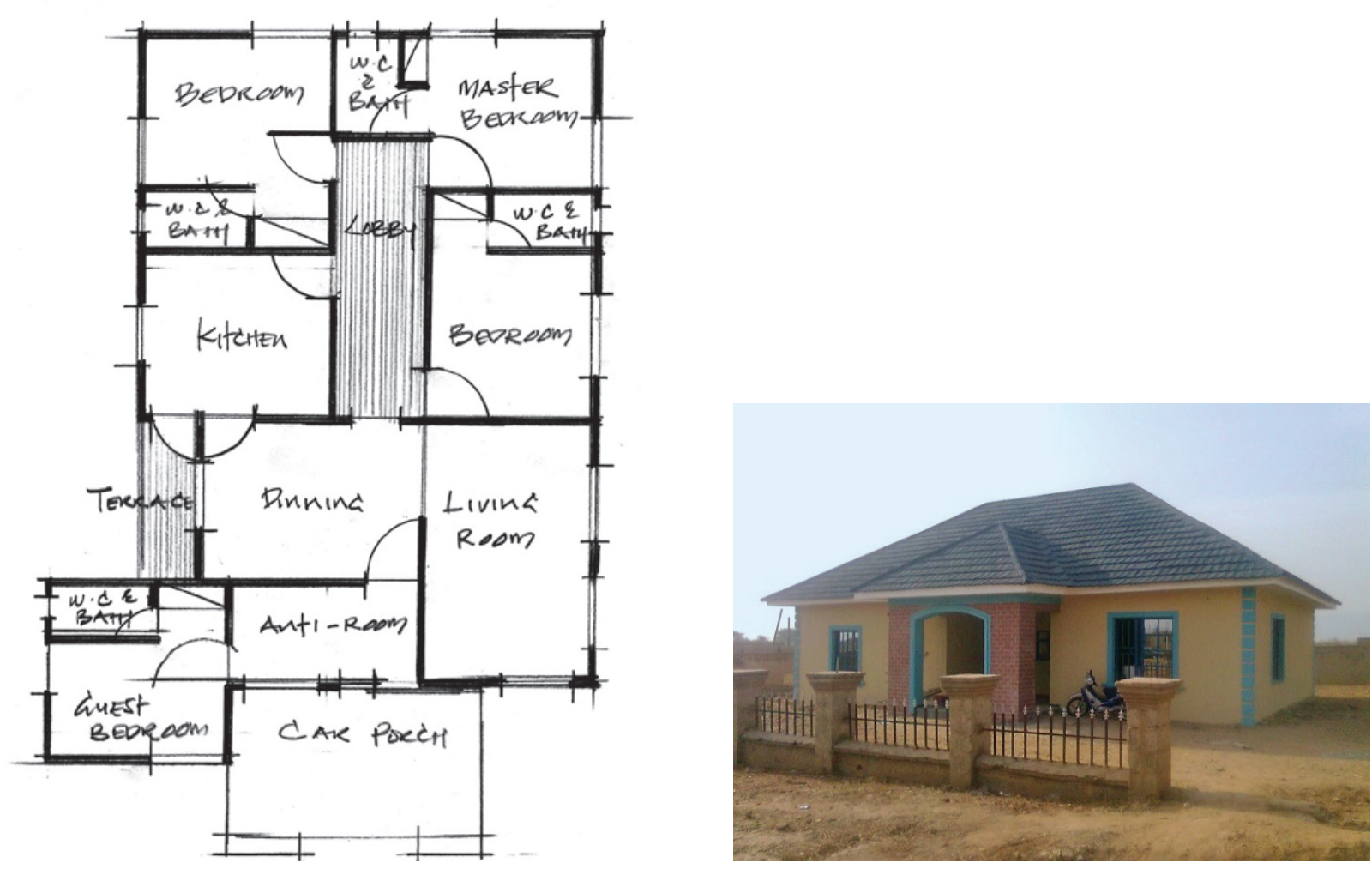

Fig. 9. Floor plan and picture of a detached bungalow house

Source: Ekhaese (2011).

\section{The detached bungalow house-types}

The Detached Bungalow House is an institutional house-type. It share similar spatial units with traditional house, but space position and house size are different. Figure 9 has a circulation lobby, this space facilitate movement of persons with the house. It has replaced the courtyard in traditional courtyard house. The convenience is clean and inside the main building as against traditional courtyard house where convenience is dirty and outside at the back section. The dinning connects the living room and the kitchen, unlike the traditional house where courtyard, kitchen, corridor act as dinning. The construction of detached bungalow follows a prototype design depending on owner's specifications and professionals' expertise. Figure 9 is a four bedroom detached bungalow house with kitchen, dining, living room etc. There is a car porch in front of the anti-room with columns acting as support to the porch roof.

The semi-detached flat house types

(single or double floor)

The Semi-detached flat House is an institutional housetype. It is recognized as semi-detached flat house because it contains two or more flats in a single building separated by partition walls for different families. House-types in this group can be single floor or multi-floors. The construction follows a prototype design, modern building materials and it is one the most sought-after house-types by individual developers, public private partnership and government, because it is economical, cultural, easy to construct and with high commercial value. However the house-type shares an identical set of spatial units with those identified in the traditional house. Figure 10 below is Single Floor-Semi-Detached Flat House-Types. The research recognized it as an institutional house-type because institution like the government first built it as quarters for workers. It is a two flats of three bedrooms each separated by a partition wall. Both flat faces the access road. Figure 11 is a double floor semi-detached House with four (4) flats of three bedrooms each for four different families and a common staircase, on a single plot. In this house-type, there can be vertical expansion as opposed to the traditional courtyard house.

\section{The detached double floor villa house-types}

The Detached Double Floor Villa House is a "contemporary house-type". The contemporary house usually has one/ more floors of concrete structural frame and sand screed block walls designed by architects. The arrangements of spaces are similar to those observed in traditional and the institutional houses, but with the introduction new spaces 

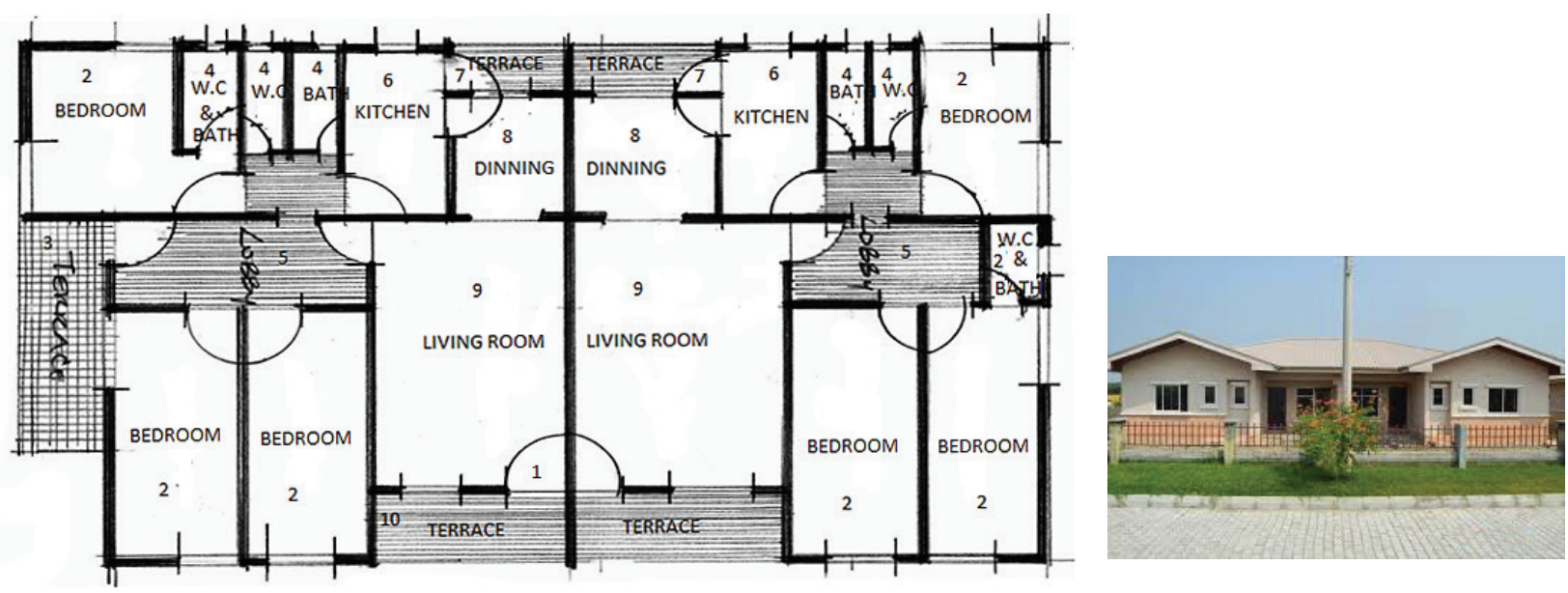

Fig. 10. Floor plan and picture of a semi-detached flat single floor house

Source: Ekhaese (2011).
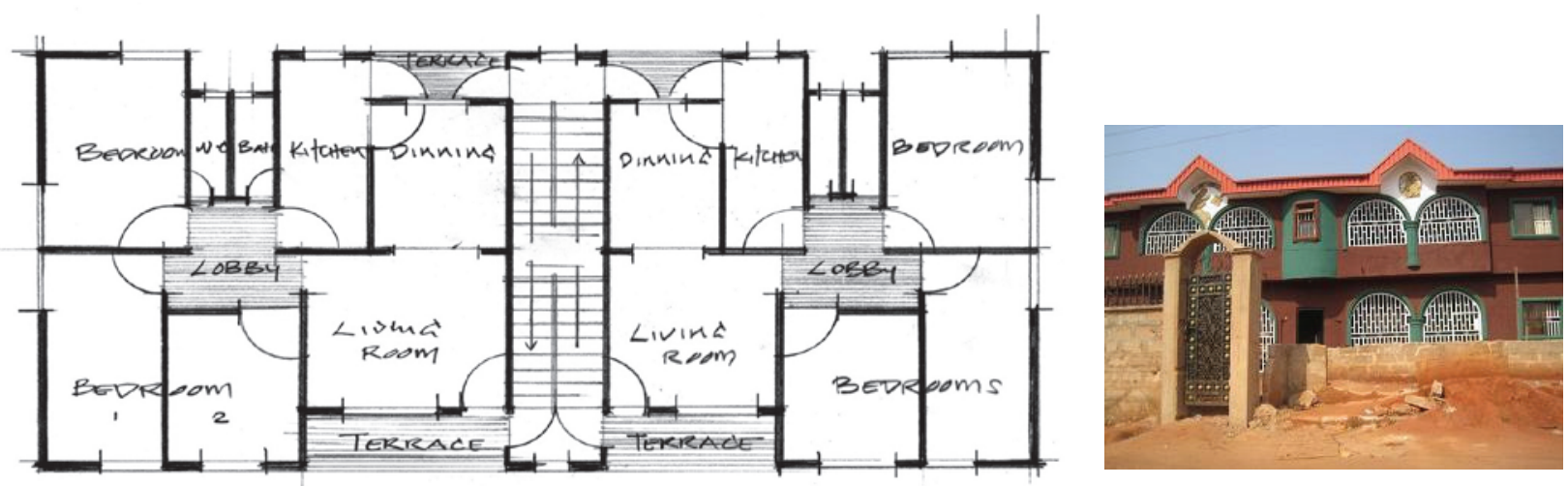

Fig. 11. Floor plan and picture of a typical semi-detached flat double floor Source: Ekhaese (2011).
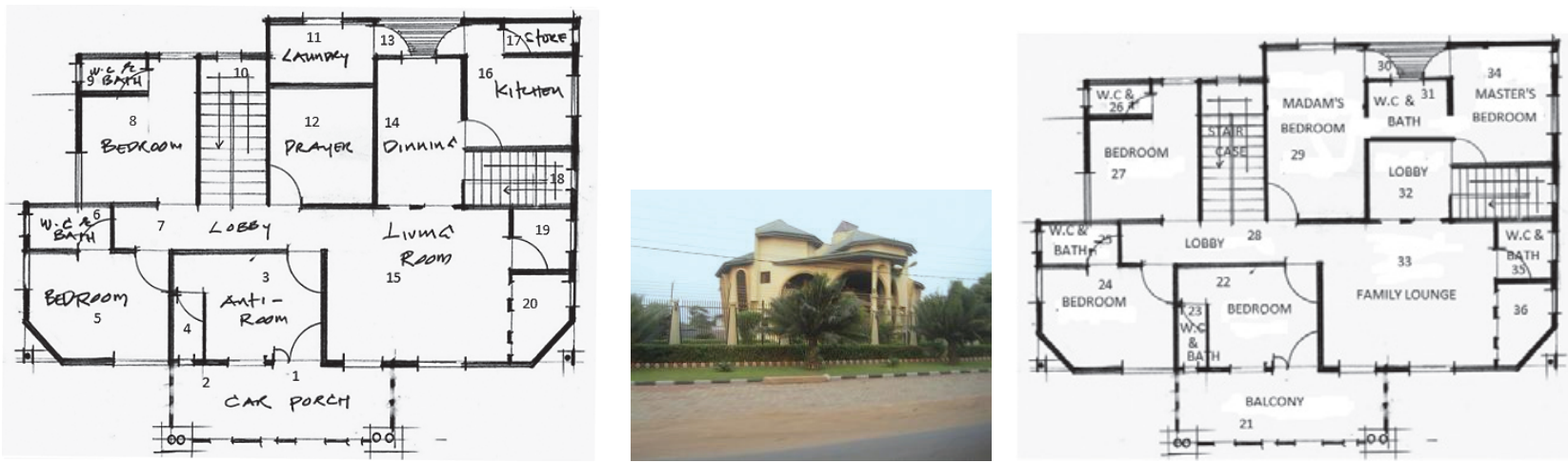

Fig. 12. Ground, upper floor plan and picture of a detached double floor villa house Source: Ekhaese (2011). 
like garage, laundry, patio, study, guest bedroom, visitor's convenience and gym/sport room. Figure 12 is a detached double floor villa house with entrance staircase and escape staircase for emergency/fire outbreak. The house-type usually has the public area and private area. The car porch doubles as entrance porch from where the living room is accessed and through to dining room with a door linking kitchen and store through the terrace at the back to laundry. Still on the ground floor is the prayer room, a niche and two en-suite guest bedrooms. On the upper floor are bedrooms gym/sport room, study and family lounge.

\section{Characteristics of the houses}

The house-types characteristics of the four residential zones of Benin City are presented below. This includes tenure composition, number of households, length of stay, age of construction and house builder/owner.

\section{Tenure composition}

Table 3 shows that in core zone, 14 houses were owner occupier (i.e. occupied by only family members, spanning generations) 90 houses were owners and tenants occupied, i.e. family members with rooms and shops for commercial purposes. This reveals that it is a zone of closely-related-family-lineage; Benin family house is held as a sacred symbol of culture and heritage. In the intermediate zone, 103 houses were owner occupied, 167 houses were owner and tenants occupied and 83 houses were tenants occupied, revealing that house-types here allows heterogeneity of family, tribes and it is different from houses in core zone. In the suburban zone, 160, 209 and 90 houses were owner occupied, owner and tenants occupied and tenants only respectively. This shows that house-types in suburban zone are similar to those in intermediate zone. While in planned estate zone, the distribution of owner occupier type shows that it is the most predominant types which suggest that family size is reducing, but owner and tenants' occupied type is more predominant in intermediate and suburban zones. This implies that planned estates houses are different from the other three zones. Admittedly there are more contemporary designs in planned estate and more traditional courtyard design in core zone. The summary of data in Table 3 show that $31 \%$ of houses were owner occupied, $49 \%$ were owners and tenants occupied and 20\% were tenants occupied. This revealed that most houses in Benin are shared by owners and tenants.

\section{Number of households}

In the core zone, 30 houses have as high as 11-15 households which show that core zone houses are large and spacious and allow multiple household to reside. But in intermediate and sub-urban zone, 659 houses had between 4-5

Table 3. Tenure composition

\begin{tabular}{|l|c|c|c|c|c|c|c|c|}
\hline \multirow{2}{*}{ Location of houses } & \multicolumn{2}{|c|}{ Core Zone } & \multicolumn{2}{|c|}{ Intermediate Zone } & \multicolumn{2}{c|}{ Sub-Urban Zone } & Planned Estate \\
\cline { 2 - 10 } & \multicolumn{2}{|c|}{$\begin{array}{c}\text { Frequency \& Valid } \\
\text { Percent }\end{array}$} & \multicolumn{2}{c|}{$\begin{array}{c}\text { Frequency \& Valid } \\
\text { Percent }\end{array}$} & \multicolumn{2}{|c|}{$\begin{array}{c}\text { Frequency \& Valid } \\
\text { Percent }\end{array}$} & $\begin{array}{c}\text { Frequency \& Valid } \\
\text { Percent }\end{array}$ \\
\hline Owner Occupied & 14 & 13.5 & 103 & 29.2 & 160 & 34.9 & 52 & 38.2 \\
\hline Owner and Tenants & 90 & 86.5 & 167 & 47.3 & 209 & 45.5 & 49 & 36.0 \\
\hline Tenants Only & & & 83 & 23.5 & 90 & 19.6 & 35 & 25.7 \\
\hline Total & 104 & 100.0 & 353 & 100.0 & 459 & 100.0 & 136 & 100.0 \\
\hline
\end{tabular}

Source: Ekhaese (2011).

Table 4. Number of households in the house

\begin{tabular}{|c|c|c|c|c|c|c|c|c|}
\hline \multirow{3}{*}{$\begin{array}{l}\text { Number of households } \\
1.00-4.00\end{array}$} & \multirow{2}{*}{\multicolumn{2}{|c|}{$\begin{array}{c}\text { Core Zone } \\
\begin{array}{c}\text { Frequency \& Valid } \\
\text { Percent }\end{array}\end{array}$}} & \multirow{2}{*}{\multicolumn{2}{|c|}{$\begin{array}{c}\text { Intermediate Zone } \\
\begin{array}{c}\text { Frequency \& Valid } \\
\text { Percent }\end{array}\end{array}$}} & \multirow{2}{*}{\multicolumn{2}{|c|}{$\begin{array}{c}\text { Sub-Urban Zone } \\
\begin{array}{c}\text { Frequency \& Valid } \\
\text { Percent }\end{array}\end{array}$}} & \multirow{2}{*}{\multicolumn{2}{|c|}{$\begin{array}{c}\text { Planned Estate } \\
\begin{array}{c}\text { Frequency \& Valid } \\
\text { Percent }\end{array}\end{array}$}} \\
\hline & & & & & & & & \\
\hline & - & - & - & - & - & - & 101 & 78.7 \\
\hline $4.00-5.00$ & 67 & 64.5 & 331 & 93.8 & 328 & 71.5 & - & - \\
\hline $6.00-10.00$ & - & - & - & - & - & - & - & - \\
\hline $11.00-5.00$ & 30 & 28.9 & - & - & - & - & - & - \\
\hline
\end{tabular}

Source: Ekhaese (2011). 
households making house-type in the two zones slightly different from those in core zone. In planned estate zone all houses have between 1-4 households revealing that the size, materials and designs of house-type here is different, smallest and has the fewest spatial units. The summary of Table 4 shows that $9 \%$ were occupied by 1-4 households, $89 \%$ were occupied by between $4-5$ household and only $2 \%$ were occupied by $11-15$ persons. It reveals that most of the house-types across the first three zones (core, intermediate and sub-urban) have similarities.

\section{Length of stay}

The lengths of years spent in the houses were analysed and Table 5 revealed that length of stay in houses in core zone is permanent (i.e. place of birth). 103 owners have lived 30 years and above in the core zone, revealing that houses are old-traditional-inherited. In the intermediate zone, 129 residents have stayed from $0-10$ years, 60 have stayed from $10-15$ years, yet 31 have spent at least $15-20$ years, 46 residents have stayed $20-30$ and the remaining 87 residents have stayed 30 years and above. This reveals that house-types and spaces in intermediate zone are more flexible, organized and heterogenic families design i.e. both owner and tenant. There are similarity in houses identified in sub-urban zones and intermediate zone. But the difference is that houses in sub-urban zone are more recently built which explains why 199 and 133 residents have lived only between $0-10$ years and $10-15$ years respectively i.e. about $72.8 \%$ of residents in sub-urban zone. The same trend in sub-urban zone is repeated in planned estate, hence allowing planned estate zone and sub-urban zone to have similarities in style, size and materials. In sum, 38\% have spent less than 10 years while $21 \%$ have spent less than 15 years. $11 \%$. have spent less than 20 years, $10 \%$, have spent less than 30 years and $21 \%$ have spent 30 years and above.

\section{Age of the house}

Years of construction of houses were analysed. The analysis revealed that most, of the houses in the core zone were built in $17^{\text {th }}, 18^{\text {th }}, 19^{\text {th }}$ and early $20^{\text {th }}$ century. This means

Table 5. Length of stay in the house

\begin{tabular}{|l|c|c|c|c|c|c|c|c|}
\hline \multirow{2}{*}{ Location of Houses } & \multicolumn{2}{|c|}{ Core Zone } & \multicolumn{2}{c|}{ Intermediate Zone } & \multicolumn{2}{c|}{ Sub-Urban Zone } & \multicolumn{2}{c|}{ Planned Estate } \\
\cline { 2 - 10 } & \multicolumn{2}{|c|}{$\begin{array}{c}\text { Frequency \& Valid } \\
\text { Percent }\end{array}$} & \multicolumn{2}{c|}{$\begin{array}{c}\text { Frequency \& Valid } \\
\text { Percent }\end{array}$} & \multicolumn{2}{c|}{$\begin{array}{c}\text { Frequency \& Valid } \\
\text { Percent }\end{array}$} & \multicolumn{2}{c}{$\begin{array}{c}\text { Frequency \& Valid } \\
\text { Percent }\end{array}$} \\
\hline $0-10$ yrs & 1 & 1.0 & 129 & 36.5 & 199 & 43.6 & 64 & 47.1 \\
\hline $10-15$ yrs & - & - & 60 & 17.0 & 133 & 29.2 & 22 & 16.2 \\
\hline $15-20$ yrs & - & - & 31 & 8.8 & 64 & 14.0 & 15 & 11.0 \\
\hline $20-30$ yrs & - & - & 46 & 13.0 & 37 & 8.1 & 23 & 16.9 \\
\hline 30 yrs and above & 103 & 99.0 & 87 & 24.6 & 23 & 5.0 & 12 & 8.8 \\
\hline Total & 104 & 100.0 & 353 & 100.0 & 456 & 100.0 & 136 & 100.0 \\
\hline
\end{tabular}

Source: Ekhaese (2011).

Table 6. Age of house

\begin{tabular}{|c|c|c|c|c|c|c|c|c|}
\hline \multirow{3}{*}{$\begin{array}{l}\text { Location of Houses } \\
17 \text { th Century }\end{array}$} & \multirow{2}{*}{\multicolumn{2}{|c|}{$\begin{array}{l}\text { Core Zone } \\
\begin{array}{c}\text { requency \& Valid } \\
\text { Percent }\end{array}\end{array}$}} & \multirow{2}{*}{\multicolumn{2}{|c|}{$\begin{array}{c}\text { Intermediate Zone } \\
\text { Frequency \& Valid } \\
\text { Percent }\end{array}$}} & \multirow{2}{*}{\multicolumn{2}{|c|}{$\begin{array}{c}\text { Sub-Urban Zone } \\
\text { Frequency \& Valid } \\
\text { Percent }\end{array}$}} & \multirow{2}{*}{\multicolumn{2}{|c|}{$\begin{array}{c}\text { Planned Estate } \\
\begin{array}{c}\text { Frequency \& Valid } \\
\text { Percent }\end{array}\end{array}$}} \\
\hline & & & & & & & & \\
\hline & 40 & 38.5 & 6 & 1.8 & 7 & 1.5 & & \\
\hline 18th Century & 42 & 40.4 & 6 & 1.8 & 10 & 2.2 & & \\
\hline 19th Century & - & - & 11 & 3.3 & 12 & 2.6 & 2 & 1.5 \\
\hline $1900-1970$ & 22 & 21.2 & 8 & 2.4 & 12 & 2.6 & 3 & 2.3 \\
\hline In The $1970 \mathrm{~s}$ & - & - & 98 & 29.7 & 62 & 13.5 & 30 & 22.9 \\
\hline In The $1980 \mathrm{~s}$ & - & - & 131 & 39.7 & 113 & 24.6 & 37 & 28.2 \\
\hline In The $1990 \mathrm{~s}$ & - & - & 49 & 14.8 & 173 & 37.7 & 47 & 35.9 \\
\hline After Year 2000 & - & - & 21 & 6.4 & 70 & 15.3 & 12 & 9.2 \\
\hline Total & 104 & 100.0 & 330 & 100.0 & 459 & 100.0 & 131 & 100.0 \\
\hline
\end{tabular}

Source: Ekhaese (2011). 
that most of the houses in core zone were over 450 years, i.e. four and half centuries. Thus making the houses style, design and materials are very old. From Table 6 below the frequencies and valid percentages in intermediate zone and sub-urban zone reveal those houses are distributed along all ages of construction showing that virtually all housetypes present in the City can be identified in the two zones. The style, pattern, size and materials of house-types here are both similar and different from those found in core zone and planned estate zone. In planned estate zone, age of construction of houses shows that houses here are more recent and contemporary $\left(20^{\text {th }}-21^{\text {st }}\right.$ century) (47 and 37 respectively). In summary, 17th century houses accounted for $5 \%, 18^{\text {th }}$ century accounted for $6 \%, 19^{\text {th }}$ century accounted for $2 \%$. However, $4 \%$ are between 1900 and 1970 . $19 \%$ in the 1970 s, $27 \%$ in the 1980 s while $26 \%$ in the 1990 s and $10 \%$ were built after year 2000 .

\section{Owner}

Table 7 revealed that 81 out of 104 houses in core zone were built by great-grand-father, 19 houses by grand-father, only 3 houses were built by father and only 1 house has it owner alive. It shows that the design, pattern and material used in core zone are the "Edo traditional courtyard house". In intermediate, sub-urban and planned estate zones, house owners are represented in all the categories of owner listed, from great-grand father to I don't know. However, in intermediate zone the highest numbers of 124 houses are owned by fathers showing that there is still this "family house thing". And in sub-urban zone fathers also owns majority of houses (184 houses) next are strangers as owners (102 houses), this shows a mixture of "family house" and "institutional house-type", thus the house-type design and material in sub-urban zone is simi- lar and different from intermediate and core zone. Owners in planned estate, fall under the categories of don't know and strangers (43 and 22) showing that house here are built for rentage and as such tenant do not know owners. Therefore $33 \%$ were owned by fathers, $9 \%$ by grandfathers, $9 \%$ by great grandfathers, $15 \%$ by strangers and $20 \%$ of those buildings were not reported.

The summary of data interpretation thus far for identification of house-type in Benin has revealed that there are several house-types across the four residential zones of the City; ages, owners and number of households in core zone shows that houses here are the oldest and largest in the City. The statistics of houses in intermediate and suburban zones reveal similarity in types and some a continuation of house types in core zone. In planned estate, the data shows that houses here are the newest, and smallest. Consequently house-type have been classified into between four to six (4-6) categories in each of the four residential zones in Benin, validating the fact that classification and analysis of house-type have been documented according to zones.

\section{Concluding remarks}

The houses in Benin have been examined on the basis of types and characteristics. Given the available facts, eleven house-types have been identified. These plans were classified based on spatial morphology across the four (core, intermediate, suburban and planned estate) residential zones in Benin City and certain variables were used to characterize houses in types; these include tenure composition, number of households, length of stay, age of house and owner of house. The tenure composition revealed that house types in Benin were occupied by both owners and tenants, number of households showed that

Table 7. Owner of house

\begin{tabular}{|l|c|c|c|c|c|c|c|c|}
\hline \multirow{2}{*}{ Location of Houses } & \multicolumn{2}{|c|}{ Core Zone } & \multicolumn{2}{c|}{ Intermediate Zone } & \multicolumn{2}{c|}{ Sub-Urban Zone } & \multicolumn{2}{c|}{ Planned Estate } \\
\cline { 2 - 11 } & \multicolumn{2}{|c|}{$\begin{array}{c}\text { Frequency \& Valid } \\
\text { Percent }\end{array}$} & \multicolumn{2}{c|}{$\begin{array}{c}\text { Frequency \& Valid } \\
\text { Percent }\end{array}$} & \multicolumn{2}{c|}{$\begin{array}{c}\text { Frequency \& Valid } \\
\text { Percent }\end{array}$} & \multicolumn{2}{c|}{$\begin{array}{c}\text { Frequency \& Valid } \\
\text { Percent }\end{array}$} \\
\hline Father & 3 & 2.9 & 124 & 35.1 & 184 & 40.3 & 32 & 23.5 \\
\hline Grandfather & 19 & 18.3 & 38 & 10.8 & 18 & 3.9 & 14 & 10.3 \\
\hline Great Grandfather & 81 & 77.9 & 7 & 2.0 & 5 & 1.1 & 2 & 1.5 \\
\hline Stranger & - & - & 35 & 9.9 & 102 & 22.3 & 22 & 16.2 \\
\hline Don't Know & - & - & 104 & 29.5 & 70 & 15.3 & 43 & 31.6 \\
\hline Husband & - & - & 1 & .3 & 1 & .2 & - & - \\
\hline Owner & 1 & 1.0 & 30 & 8.5 & 74 & 16.2 & 19 & 14.0 \\
\hline Relatives & - & - & 14 & 4.0 & 3 & .7 & 4 & 2.9 \\
\hline Total & 104 & 100.0 & 353 & 100.0 & 457 & 100.0 & 136 & 100.0 \\
\hline
\end{tabular}

Source: Ekhaese (2011). 
the average number of households in houses across the residential zone is between 4 and 5 households, which imply that most of houses are compound houses. The length of stay, age and owner of house reveal that the oldest and largest houses are found in core areas, while the newest and most single family houses are found in planned estate. With reference to Table 2, three (3) house types were identified in core zone (i.e. courtyard house types). Seven (7) house types were identified in intermediate zone: few courtyard house types but modified, corridor house types and a pocket of institutional house types. But in suburban zone, five (5) house types were recognized: modified courtyard house type, institutional house types and contemporary house types. In planned estate zone, four (4) house types were noticed; with little or no trace of courtyard house types, because all house types found here were mainly contemporary and a few institutional house types. Thus in all the eleven house types identified across the entire City, at least four to six (4-6) house-types can be found in each of the four residential zones. However, an attempt has been made to classify houses in Benin into house-types across residential zone, based on spatial organization and arrangement which is typical of a traditional city.

\section{References}

Abakare, E. 2013. Benin City walls and moat outline action plan. Catech.

Agbontaen, K. A.; Ogunje, A. A.; Oladipupo, A. O. 1996. The impluvium-courtyard (oto-eghodo) in indigenous Benin Architecture, Nigerian Field 61(1-2): 54-64.

Agbontaen, K. A. 1997. An assessment of four centuries (15th 19th) of Benin art production in evaluating the role of craft guild system on Benin Polity, African Study Monographs 18(1): 45-58.

Aisien, E. 2001. The Benin City pilgrimage stations. Benin City: Aisien publishers.

Alonso, W. 1964. Location and land use. Harvard University Press. https://doi.org/10.4159/harvard.9780674730854

Assari, A.; Mahesh, T. M.; Assari, E. 2012. Conservation of historic urban core in traditional islamic culture: case study of Isfahan City, Indian Journal of Science and Technology 5(1): 1970-1976.

Bertaud, A. 2004. The spatial organization of cities: deliberate outcome or unforeseen consequence? Institute of Urban and regional Development, Berkeley: University of California.

Bruekner, J. K. 2001. Urban sprawl: lessons from urban economics, in W. G. Gale, J. R. Pack (Eds.). Brookings-Wharton papers on urban affairs. Brookings Institution, Washington, D.C.
Ekhaese E. N. 2011. Domestic architecture in Benin City: a study of continuity and change, an unpublished PhD Thesis Department of Architecture, School of Environmental Science, Covenant University, Ota, Ogun, Nigeria.

Ekhaese, E. N.; Amole, B. 2014a. Benin domestic architecture " $a$ tabula rasa" for transition: from pre-independence to contemporary architecture, International Journal of Social Sciences and Entrepreneurship 1(9): 264-287.

Ekhaese, E. N.; Adeboye, A. B. 2014b. Go-ahead element of domestic architecture: socio- economic and cultural characteristics of the residents in Benin, IMPACT: International Journal of Research in Humanities, Arts and Literature 2(5): 73-88.

Ju, S. R.; Kim, B. M.; Ariffin, S. I. 2015. Continuation and transformation of traditional elements in colonial vernacular houses in kampong Bharu, Malaysia, Journal of Asian Architecture and Building Engineering JAABE 14(2): 346. https:// doi.org/10.3130/jaabe.14.339

Li, X. 1985. The spatial structure and land use pattern of cities in Taihu Lake, late 19th century to present em, Cheng Shi Gui Hua Hui Kan 39(1): 10.

Miao, P. 1990. Seven characteristics of traditional urban form in South East China, TDSR Journal 1(2): 35-47.

Mills, E. S. 1972. Studies in the structure of the urban economy. Baltimore, Maryland: Johns Hopkins Press.

Mills, E. S; Byong-Nak, S. 1979. Urbanization and urban problems. Harvard, University Asia Center. https://doi.org/10.2307/j.ctt1tg5jv2

Muth, R. F. 1969. Cities and housing. Chicago: University of Chicago press.

Ogu, V. I. 1995. Private sector participation and municipal waste management in Benin Nigeria, Environment and Urbanization 12(2): 103-117. https://doi.org/10.1177/095624780001200209

Omoigui, I. 2005. How to improve youth development in Edo state, a key note presentation on excellence in education and culture for the new millennium, 14th Annual National Convention of the Edo National Association of USA and Canada. On the first report of the SFHA, San Francisco Housing Association 13(1): 6 .

Ramezan, S.; Hamidi, S. 2010. Privacy and Social interaction in traditional towns to contemporary urban design in Iran, American Journal of Engineering and Applied Sciences 3(3): 501-508. https://doi.org/10.3844/ajeassp.2010.501.508

Saga, A. 2012. From the traditional city to the modern city: based on studies of urban regional societies in 19th century Osaka, Urban Scope 3: 34-54.

Stark, O.; Simon Fan, C. 2007. The analytics of seasonal migration, Economics Letters 94: 304-312.

https://doi.org/10.1016/j.econlet.2006.10.017

UNESCO. 2010. Preliminary report on the draft recommendation on the historic urban landscape. UNESCO World Heritage Centre, Paris. 


\section{EGHOSA NOEL EKHAESE}

He is a Doctor of philosophy in Architecture, a research fellow and a lecturer, Department of Architecture, College of science and technology, School of Environmental Science, Covenant University, Ota, Ogun, Nigeria. His area of interest encompasses interdisciplinary and multi-disciplinary research based on Built Environment, Domestic Architecture theories, Culture, and Behavioural Science. Dr Ekhaese is an Architect, with research interest in Space morphology, culture and Environmental health/ well-being. He has years of experience in working with communities. He and sub-cluster team members has won a Grant for \#4.6million to conduct a research across the 6 Geo-political Zone of Nigeria Environmental, Occupation, Family \& lifestyle Factors As Predictors of Health/Psychological Wellbeing (under Wellbeing and behavioural Issue cluster). He is a member Nigerian Institute of Architects (MNIA), Member architectural association of educators (AARCHIES), Member Co-operative Network for Building Researchers (CNBR), Member European Centre for Research Training and Development, UK, Member International Journal of Social Scientist and Entrepreneur Nairobi, Kenya. Member, Harvard Business review publishing (HBP), Member, National Academies of Science, Medicine and engineering (NASME), Member, UBC postdoctoral Association, Member, Atlantic and /or CityLab, Member, Consortium of Universities for Global Health (CUGH), Member, American Chemical Society’s (ACS), DisQus@ekhaeseeghosanoel.

\section{BAYO AMOLE}

Professor of Architecture, a researcher and lecturer, Department of Architecture, Faculty of Environmental Science, Obafemi Awolowo University, Ile-Ife, Osun, Nigeria. His area of interest encompasses interdisciplinary and multi-disciplinary research based on Vernacular Architecture Domestic Architecture theories, Culture, and Behavioural Science. Prof. Amole is an Architect, with research interest in African Folk Architecture, culture and History. He has years of experience in working with communities both within and outside the African continent.

\section{OLADUNNI IZOBO-MARTINS}

Dr is a lecturer in the Department of Architecture, Covenant University, Ota. She obtained her BTech. M.Tech Architecture from Federal University of Technology Akure and PhD Architecture degree from the Covenant University, Ota, Ogun State, Nigeria in 2014. Her career in lecturing spans over eight years. Her research work is on public building Maintenance and services. Building Services and Maintenance, Urban Planning, Environmental Sciences and Architectural education. She has present papers at conferences in both national and international conferences in Nigeria and UK. She has several publications in reputable journals in her field of study. 